Acta Crystallographica Section B

Structural

Science

ISSN 0108-7681

David J. Edwards, Robin G. Pritchard and Timothy W. Wallace*

School of Chemistry, The University of Manchester, Oxford Road, Manchester M13 9PL, England

Correspondence e-mail:

tim.wallace@manchester.ac.uk

\title{
Fine-tuning of biaryl dihedral angles: structural characterization of five homologous three-atom bridged biphenyls by X-ray crystallography
}

The homologous series of three-atom bridged biaryls comprising 5,7-dihydro-1,2,3,9,10,11-hexamethoxydibenzo[c,e]oxepine, 6,7-dihydro-1,2,3,9,10,11-hexamethoxy-6methyl-5H-dibenzo[c,e]azepinium chloride, 5,7-dihydro$1,2,3,9,10,11$-hexamethoxydibenzo[c,e]thiepine, and the 6oxide and 6,6-dioxide derivatives of the latter have been characterized by X-ray crystal structure analysis. Within this series the endocyclic and exocyclic biaryl dihedral angles vary over $10^{\circ}$ ranges, reflecting the changing balance of intramolecular (steric, geometric) and intermolecular (crystal packing) forces, the former being potential control elements for fine-tuning the helicity of the biaryl system.

\section{Introduction}

Biaryls with three-atom bridges connecting the 2,2'-positions have been the subject of continuing interest since the pioneering studies by Mislow and others in the 1960s into their chiroptical properties and the features which determine their configurational stability (Mislow et al., 1962, 1964; Kurland et al., 1964; Hall, 1969); more recently their biological effects have become increasingly significant. The alkaloid (-)colchicine (1) (Fig. 1) binds strongly to the protein tubulin, thereby disrupting microtubule-dependent cell functions (Boyé \& Brossi, 1992; Brossi, 1990; Le Hello, 2000), and although the therapeutic value of (1) is compromised by its toxicity, a number of related structures such as the allocolchicine derivatives (2) and (3) have similar or enhanced tubulin-binding ability (Kang et al., 1990; Boyé et al., 1993; Shi et al., 1997, 1998; Lee, 1999). From this series a phosphate prodrug, ZD6126, derived from (3), has been identified as a promising candidate for clinical use in targeting the vascular systems of solid tumours (Davis et al., 2002). It has been established that colchicine analogues only bind efficiently to tubulin if they possess, or can achieve, the same sense of helicity as the natural product (Brossi et al., 1990; Berg \& Bladh, 1999; Brossi et al., 1999). The nature of the bridging $B$ ring influences the conformational mobility of the $A-C$ axis, and in (-)-(1) the preference of the 7-substituent for an equatorial orientation effectively induces the $(\mathrm{a} R)$ configuration depicted. However, structures with an unsubstituted $B$ ring such as (4) (Banwell et al., 1992) and (5) (Boyé et al., 1989) are also efficient tubulin binders and these exist in solution as mixtures of $(\mathrm{a} R)$ - and $(\mathrm{a} S)$-atropisomers, of which the former is the active conformation (Cavazza et al., 2000; Bergemann et $a l$., 2003). The discovery that open-chain biaryls also bind to the colchicine binding site of tubulin has led to further speculation about the role of inter-aryl flexibility in the binding process (Janik \& Bane, 2002).
Received 10 December 2004 Accepted 3 March 2005
(C) 2005 International Union of Crystallography

Printed in Great Britain - all rights reserved 
Our interest in these and other aspects of biaryl conformation, in particular the principle of fine tuning the dihedral angles, led us to seek new ways of controlling this property. Using complementary kinetic and thermodynamic resolution processes we prepared the first examples, (6) and (7), of a new type of conformationally restrained bridged biaryl lactam (Edwards et al., 2003). To gain further insight into the structural characteristics of three-atom bridged biaryls, we prepared the homologous series of polymethoxylated structures (8)-(12) for analysis by X-ray crystallography. We herein describe the results of this study, which provide some direct comparison of the factors that contribute to the final threedimensional structure of such molecules.

\section{Experimental}

All compounds are racemic. Melting points were determined using a Buchi 512 or an Electrothermal 9100 apparatus and are uncorrected. IR spectra were of neat thin films on $\mathrm{NaCl}$ plates, recorded on Perkin-Elmer 1710FT or Nicolet Nexus 670/870 spectrometers. NMR spectra were measured on Bruker DPX200 $\left({ }^{1} \mathrm{H}\right.$ at $\left.200 \mathrm{MHz}\right)$, DPX300 $\left({ }^{1} \mathrm{H}\right.$ at $300 \mathrm{MHz},{ }^{13} \mathrm{C}$ at $75 \mathrm{MHz})$ or DPX400 $\left({ }^{1} \mathrm{H}\right.$ at $400 \mathrm{MHz},{ }^{13} \mathrm{C}$ at $\left.100 \mathrm{MHz}\right)$ instruments for solutions in deuteriochloroform; $J$ values are quoted to the nearest $0.5 \mathrm{~Hz}$. NMR spectra were assigned with the aid of HMQC and DEPT-135 spectra where appropriate. Mass spectra were measured on a Micromass LCT instrument using a Waters 2790 separations module with electrospray

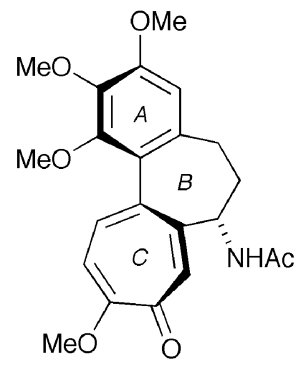

$(\mathrm{a} R, 7 S)-(1)$

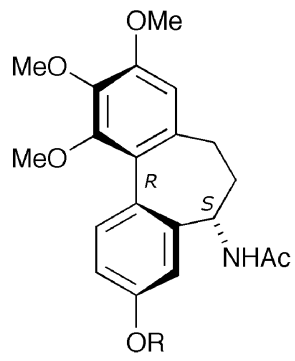

(2), $\mathrm{R}=\mathrm{Me}$

(3), $\mathrm{R}=\mathrm{H}$

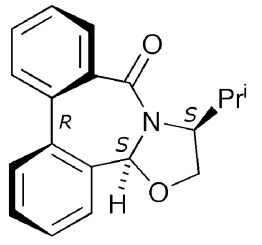

(7)

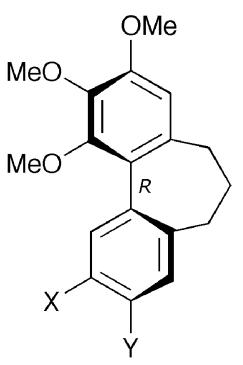

(4), $X=O M e, Y=H$ (5), $X=H, Y=O M e$

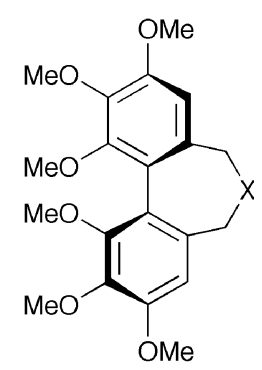

(8), $\mathrm{X}=\mathrm{O}$ (9), $X=\mathrm{NMe}$

(10), $X=S$

(11), $X=\mathrm{SO}$

(12), $\mathrm{X}=\mathrm{SO}_{2}$
Figure 1

Structures of three-atom bridged biaryls (1)-(12). ionization and TOF fragment detection. Starting materials and solvents were either used as supplied or purified by conventional techniques (Perrin et al., 1980) and most reactions were carried out under nitrogen or argon. Organic solutions were dried using anhydrous magnesium sulfate and concentrated by rotary evaporation. TLC was carried out using Merck silica gel 60 on aluminium plates and the chromatograms visualized using UV light $(254 \mathrm{~nm})$ and/or the following developing agents: ethanolic vanillin or acidified aqueous potassium permanganate. Preparative (flash) chromatography (Still et al., 1978) was carried out on $60 \mathrm{H}$ silica gel (Merck 9385). Compositions of solvent mixtures are quoted as ratios of volume. 'Ether' refers to diethyl ether.

\subsection{Dimethyl $4,4^{\prime}, 5,5^{\prime}, 6,6^{\prime}$-hexamethoxy-2, $2^{\prime}$-diphenate ( \pm )-} (14)

To a suspension of ellagic acid (13) (8.8 g, $29.1 \mathrm{mmol})$ in water $(170 \mathrm{ml})$ at room temperature tetrabutylammonium iodide (537 mg, $1.45 \mathrm{mmol}, 5 \mathrm{~mol} \mathrm{\% )}$ ) and dimethyl sulfate $(29 \mathrm{ml}, 38.66 \mathrm{~g}, 0.3 \mathrm{~mol}$ ) were added. To the vigorously stirred suspension was slowly added a solution of $\mathrm{KOH}(28.6 \mathrm{~g}$, $0.5 \mathrm{~mol})$ in water $(56 \mathrm{ml})$ over $3 \mathrm{~h}$ and the mixture was then heated under reflux for $12 \mathrm{~h}$. After cooling to room temperature, the mixture was acidified with concentrated $\mathrm{HCl}$ and extracted with DCM $(3 \times 100 \mathrm{ml})$. The organic layer was dried and evaporated to give a crude solid $(8 \mathrm{~g})$, which was dissolved in DMF $(70 \mathrm{ml})$ and treated at $273 \mathrm{~K}$ with $\mathrm{NaH}$ ( $4.79 \mathrm{~g}, 60 \%$ dispersion in mineral oil, $0.12 \mathrm{~mol}$ ). After stirring for $0.5 \mathrm{~h}$, iodomethane $(10 \mathrm{ml}, 22.8 \mathrm{~g}, 0.16 \mathrm{~mol})$ was added and the mixture was stirred overnight at room temperature. The reaction was quenched by the addition of $2 M$ hydrochloric acid $(20 \mathrm{ml})$ at $273 \mathrm{~K}$ and the mixture extracted with ether $(3 \times 100 \mathrm{ml})$. The combined extracts were dried and evaporated. Purification of the crude material by flash chromatography over silica gel $(200 \mathrm{~g})$, eluting with hexane-ethyl acetate (3:1), followed by recrystallization from ether-hexane gave the title compound (14) $(5.07 \mathrm{~g}, 39 \%)$ as a colourless solid, m.p. 352-354 K, lit. $353 \mathrm{~K}$ (Itoh et al., 1996); $\delta_{\mathrm{H}}$ $\left(300 \mathrm{MHz}, \mathrm{CDCl}_{3}\right) 7.38\left(2 \mathrm{H}, \mathrm{s}, 3\right.$ and $\left.3^{\prime}-\mathrm{H}\right), 3.97(6 \mathrm{H}, \mathrm{s}, 2 \times$ $\mathrm{OMe}), 3.95(6 \mathrm{H}, \mathrm{s}, 2 \times \mathrm{OMe}), 3.65(12 \mathrm{H}, \mathrm{s}, 2 \times \mathrm{OMe}$ and $2 \times$ $\left.\mathrm{CO}_{2} \mathrm{Me}\right) ; \delta_{\mathrm{C}}\left(75 \mathrm{MHz}, \mathrm{CDCl}_{3}\right) 52.2,56.3,60.9,61.2,109.2$, 125.4, 127.0, 145.8, 151.6, 152.4, 167.3.

\section{2. $4,4^{\prime}, 5,5^{\prime}, 6,6^{\prime}$-Hexamethoxy-1, $1^{\prime}$-biphenyl-2, 2' - dimethanol $( \pm)-(15)$}

To a suspension of $\mathrm{LiAlH}_{4}(1.14 \mathrm{~g}, 30 \mathrm{mmol})$ in dry THF $(20 \mathrm{ml})$ under argon was added a solution of (14) (4.5 g, $10.0 \mathrm{mmol})$ in dry THF $(20 \mathrm{ml})$ and the mixture was then heated under reflux for $3 \mathrm{~h}$. After being cooled to room temperature, the mixture was cautiously acidified with concentrated hydrochloric acid $(5 \mathrm{ml})$ and extracted with ether $(3 \times 100 \mathrm{ml})$. The combined extracts were dried and evaporated to give a crude solid (3.8 g), which was purified by flash chromatography over silica gel $(200 \mathrm{~g})$, eluting with hexane-ethyl acetate $\left(1: 1 ; R_{f}=0.29\right)$, followed by recrystallization from ethyl acetate-hexane, which gave the diol (15) 
(3.6 g, 91\%), m.p. 380-382 K, lit. 378-379 K (benzene-ether; Kochetkov et al., 1962); $\delta_{\mathrm{H}}\left(400 \mathrm{MHz}, \mathrm{CDCl}_{3}\right) 6.87(2 \mathrm{H}, \mathrm{s}, 3-\mathrm{H}$, $\left.3^{\prime}-\mathrm{H}\right), 4.16\left(4 \mathrm{H}, \mathrm{s}, 2 \times \mathrm{CH}_{2}\right), 3.91(6 \mathrm{H}, \mathrm{s}, 2 \times \mathrm{OMe}), 3.87(6 \mathrm{H}, \mathrm{s}$, $2 \times \mathrm{OMe}), 3.65(6 \mathrm{H}, \mathrm{s}, 2 \times \mathrm{OMe}), 2.78(2 \mathrm{H}$, br. s, $2 \times \mathrm{OH}) ; \delta_{\mathrm{C}}$ $\left(100 \mathrm{MHz}, \mathrm{CDCl}_{3}\right) 56.04,61.03,61.05,63.73\left(\mathrm{CH}_{2}\right), 108.84$ (3H, 3'-H), 121.68, 135.77, 141.69, 151.07, 153.38, consistent with published data (Warshawsky \& Meyers, 1990); $v_{\max }\left(\mathrm{cm}^{-1}\right)$ 3402, 2936, 2835, 1600, 1488, 1464, 1402, 1324, 1192, 1130, 1099, 1014, 917; m/z (ES) $347\left(50 \%, M \mathrm{H}^{+}-\mathrm{CH}_{2} \mathrm{O}\right), 377(4 \%$, $\left.M \mathrm{H}^{+}-\mathrm{H}_{2} \mathrm{O}\right), 417\left(3 \%, M \mathrm{Na}^{+}\right), 458\left(100 \%, M \mathrm{Na}_{2} \mathrm{H}_{2} \mathrm{O}^{+}\right)$.

\subsection{5,7-Dihydro-1,2,3,9,10,11-hexamethoxydibenzo[c,e]- oxepine $( \pm)-(8)$}

Concentrated hydrochloric acid $(0.2 \mathrm{ml})$ was added to a solution of the diol (15) $(160 \mathrm{mg}, 0.41 \mathrm{mmol})$ in THF ( $3 \mathrm{ml})$ and $2 M$ hydrochloric acid ( $3 \mathrm{ml}$ ), and the mixture was heated under reflux for $4 \mathrm{~h}$. The mixture was then cooled to room temperature, diluted with water $(30 \mathrm{ml})$ and extracted with ether $(3 \times 30 \mathrm{ml})$. The combined extracts were dried and evaporated to give a crude solid (142 mg), which was purified by flash chromatography over silica gel $(20 \mathrm{~g})$, eluting with hexane-ethyl acetate $\left(1: 1 ; R_{f}=0.33\right)$ to obtain the title compound $( \pm)-(8)(130 \mathrm{mg}, 85 \%)$ as colourless crystals, m.p. 417-419 K (EtOAc), lit. 420-421 K (MeOH; Kashiwada et al., 1994). Found: $\mathrm{C} 63.70, \mathrm{H} 6.55 ; \mathrm{C}_{20} \mathrm{H}_{24} \mathrm{O}_{7}$ requires $\mathrm{C} 63.82, \mathrm{H}$ $6.43 \% ; \delta_{\mathrm{H}}\left(200 \mathrm{MHz}, \mathrm{CDCl}_{3}\right) 6.72(2 \mathrm{H}, \mathrm{s}, 4-\mathrm{H}, 8-\mathrm{H}), 4.38(2 \mathrm{H}$, $\left.\mathrm{d}, J=11 \mathrm{~Hz}, 5-\mathrm{H}_{A}, 7-\mathrm{H}_{A}\right), 4.05\left(2 \mathrm{H}, \mathrm{d}, J=11 \mathrm{~Hz}, 5-\mathrm{H}_{B}, 7-\mathrm{H}_{B}\right)$, $3.92(6 \mathrm{H}, \mathrm{s}, 2 \times \mathrm{OMe}), 3.91(6 \mathrm{H}, \mathrm{s}, 2 \times \mathrm{OMe}), 3.72(6 \mathrm{H}, \mathrm{s}, 2 \times$ $\mathrm{OMe}) ; \delta_{\mathrm{C}}\left(100 \mathrm{MHz}, \mathrm{CDCl}_{3}\right) 56.16,60.88,61.12,67.59$ (5-C, $7-$ C), 107.98 (4-C, 8-C), 123.18, 130.94, 142.40, 151.36, 153.40; $v_{\max }\left(\mathrm{cm}^{-1}\right) 2983,2940,2855,1599,1492,1463,1403,1318$, $1238,1191,1127,1097 ; \mathrm{m} / z$ (ES) $347\left(8 \%, M \mathrm{H}^{+}-\mathrm{CH}_{2} \mathrm{O}\right), 377$ $\left(2 \%, M \mathrm{H}^{+}\right), 399\left(3 \%, M \mathrm{Na}^{+}\right), 440\left(100 \%, M \mathrm{Na}_{2} \mathrm{H}_{2} \mathrm{O}^{+}\right)$.

\section{4. ( \pm )-2,2'-Bis(bromomethyl)-5,7-dihydro- $4,4^{\prime}, 5,5^{\prime}, 6,6^{\prime}$ - hexamethoxy-1,1'-biphenyl (16)}

Phosphorus tribromide (417 $\mathrm{mg}, 1.54 \mathrm{mmol}$ ) was added to a solution of the diol (15) (0.92 g, $2.33 \mathrm{mmol})$ in DCM (20 ml) and the mixture was stirred for $1 \mathrm{~h}$. TLC indicated complete conversion and water $(30 \mathrm{ml})$ was then added. The organic phase was then separated and the aqueous phase extracted with DCM $(2 \times 30 \mathrm{ml})$. The combined extracts were dried and evaporated in vacuo to give the crude dibromide (16), which was used without further purification.

\subsection{6,7-Dihydro-1,2,3,9,10,11-hexamethoxy-6-methyl-5H- dibenzo[c,e]azepine $( \pm)-(9)$}

Methylamine hydrochloride $(0.181 \mathrm{~g}, 2.68 \mathrm{mmol})$ and triethylamine $(0.475 \mathrm{~g}, 4.7 \mathrm{mmol})$ were added to a solution of the dibromide (16), prepared as described above from the diol (15) $(0.67 \mathrm{mmol})$, in dry DMF $(2 \mathrm{ml})$ at $273 \mathrm{~K}$ under argon, and the mixture was stirred overnight at room temperature. Water $(20 \mathrm{ml})$ was added and the mixture was extracted with ethyl acetate $(3 \times 20 \mathrm{ml})$. The combined organic extract was washed with brine $(20 \mathrm{ml})$, dried and evaporated in vacuo. Flash chromatography of the residue over silica gel $(50 \mathrm{~g})$, eluting with ethyl acetate, followed by crystallization from ethyl acetate yielded the title compound (9) (166 mg, 64\%) as a colourless solid, m.p. 401-402 K. Found: C 64.7, H 6.6, N 4.0; $\mathrm{C}_{21} \mathrm{H}_{27} \mathrm{NO}_{6}$ requires C 64.77, $\mathrm{H}, 6.99, \mathrm{~N} 3.60 \% ; \delta_{\mathrm{H}}(400 \mathrm{MHz}$, $\left.\mathrm{CDCl}_{3}\right) 6.64(2 \mathrm{H}, \mathrm{s}, 4-\mathrm{H}, 8-\mathrm{H}), 3.90(6 \mathrm{H}, \mathrm{s}, 2 \times \mathrm{OMe}), 3.89(6 \mathrm{H}$, $\mathrm{s}, 2 \times \mathrm{OMe}), 3.69(6 \mathrm{H}, \mathrm{s}, 2 \times \mathrm{OMe}), 3.34(2 \mathrm{H}, \mathrm{d}, J=12.5 \mathrm{~Hz}, 5-$ $\left.\mathrm{H}_{A}, 7-\mathrm{H}_{A}\right), 3.09\left(2 \mathrm{H}, \mathrm{d}, J=12.5 \mathrm{~Hz}, 5-\mathrm{H}_{B}, 7-\mathrm{H}_{B}\right), 2.36(3 \mathrm{H}, \mathrm{s}$, $\mathrm{NMe}) ; \delta_{\mathrm{C}}\left(100 \mathrm{MHz}, \mathrm{CDCl}_{3}\right)$ 43.00, 56.15, 57.19 (5-C, 7-C), 60.82, 61.12, 108.21 (4-C, 8-C), 122.73, 130.03, 141.76, 151.48, 152.88; $v_{\max }\left(\mathrm{cm}^{-1}\right)$ 2940, 2835, 2788, 1596, 1487, 1464, 1410, 1363, 1320, 1243, 1130, 1107; $\mathrm{m} / \mathrm{z}$ (ES) $390\left(100 \%, \mathrm{MH}^{+}\right)$.

\subsection{5,7-Dihydro-1,2,3,9,10,11-hexamethoxydibenzo[c,e]- thiepine $( \pm)-(10)$}

Sodium sulfide nonahydrate $(0.483 \mathrm{~g}, 2.0 \mathrm{mmol})$ and triethylamine $(0.204 \mathrm{~g}, 2.0 \mathrm{mmol})$ was added to a solution of the dibromide (16), prepared as described above from the diol (15) $(0.67 \mathrm{mmol})$, in dry DMF $(2 \mathrm{ml})$ at $273 \mathrm{~K}$ under argon, and the mixture stirred overnight at room temperature. Water $(20 \mathrm{ml})$ was added and the mixture extracted with ethyl acetate $(3 \times 20 \mathrm{ml})$. The combined organic extract was washed with brine $(20 \mathrm{ml})$, dried and evaporated in vacuo. Flash chromatography of the residue over silica gel $(50 \mathrm{~g})$, eluting with ethyl acetate, followed by crystallization from ethyl acetate yielded the title compound (10) $(230 \mathrm{mg}, 87 \%)$ as a colourless solid, m.p. 482-484 K. Found: C 61.2, H 6.1, S 8.1; $\mathrm{C}_{20} \mathrm{H}_{24} \mathrm{O}_{6} \mathrm{~S}$ requires C 61.21, H 6.16, S 8.17\%; $\delta_{\mathrm{H}}(400 \mathrm{MHz}$, $\left.\mathrm{CDCl}_{3}\right) 6.63(2 \mathrm{H}, \mathrm{s}, 4-\mathrm{H}, 8-\mathrm{H}), 3.90(6 \mathrm{H}, \mathrm{s}, 2 \times \mathrm{OMe}), 3.88(6 \mathrm{H}$, $\mathrm{s}, 2 \times \mathrm{OMe}), 3.67(6 \mathrm{H}, \mathrm{s}, 2 \times \mathrm{OMe}), 3.40(2 \mathrm{H}, \mathrm{d}, J=12.5 \mathrm{~Hz}, 5-$ $\left.\mathrm{H}_{A}, 7-\mathrm{H}_{A}\right), 3.23\left(2 \mathrm{H}, \mathrm{d}, J=12.5 \mathrm{~Hz}, 5-\mathrm{H}_{B}, 7-\mathrm{H}_{B}\right) ; \delta_{\mathrm{C}}(100 \mathrm{MHz}$, $\mathrm{CDCl}_{3}$ ) 32.21 (5-C, 7-C), 56.09, 60.67, 61.10, 106.68 (4-C, 8-C), $122.01,131.45,141.45,151.39,153.62 ; v_{\max }\left(\mathrm{cm}^{-1}\right) 2928,1594$, 1488, 1458, 1399, 1318, 1242, 1199, 1093, 1008; $\mathrm{m} / \mathrm{z}$ (ES) 393 $\left(8 \%, M \mathrm{H}^{+}\right), 415\left(4 \%, M \mathrm{Na}^{+}\right), 456\left(100 \%, M \mathrm{Na}_{2} \mathrm{H}_{2} \mathrm{O}^{+}\right)$.

\subsection{5,7-Dihydro-1,2,3,9,10,11-hexamethoxydibenzo[c,e]- thiepine 6-oxide $( \pm)-(11)$ and 5,7-dihydro-1,2,3,9,10,11- hexamethoxydibenzo[c,e]thiepine 6,6-dioxide $( \pm)-(12)$}

$m$-Chloroperbenzoic acid (41 mg, purity ca $70 \%$, $0.17 \mathrm{mmol}$ ) was added to a solution of $( \pm)-(10)(66 \mathrm{mg}$, $0.17 \mathrm{mmol})$ in acetone $(1 \mathrm{ml})$. The mixture was stirred at $273 \mathrm{~K}$ for $5 \mathrm{~h}$, then cooled to room temperature, diluted with water $(10 \mathrm{ml})$ and extracted with ether $(3 \times 10 \mathrm{ml})$. The combined extracts were dried and evaporated to give a crude solid (62 mg) which was purified by flash chromatography over silica gel (10 g), eluting initially with ethyl acetate and later with ethyl acetate-methanol (10:1). The first fractions gave the title sulfone (12) (18 mg, 25\%) as colourless crystals, m.p. $497 \mathrm{~K}$ (EtOAc). Found: C 56.7, H 5.8, S 7.5; $\mathrm{C}_{20} \mathrm{H}_{24} \mathrm{O}_{8} \mathrm{~S}$ requires C $56.59, \mathrm{H} 5.70, \mathrm{~S} 7.55 \%$; $\delta_{\mathrm{H}}\left(400 \mathrm{MHz}, \mathrm{CDCl}_{3}\right) 6.75$ $(2 \mathrm{H}, \mathrm{s}, 4-\mathrm{H}, 8-\mathrm{H}), 3.98\left(2 \mathrm{H}, \mathrm{d}, J=13.5 \mathrm{~Hz}, 5-\mathrm{H}_{A}, 7-\mathrm{H}_{A}\right), 3.92$ $(6 \mathrm{H}, \mathrm{s}, 2 \times \mathrm{OMe}), 3.90(6 \mathrm{H}, \mathrm{s}, 2 \times \mathrm{OMe}), 3.86(2 \mathrm{H}, \mathrm{d}, J=$ $\left.13.5 \mathrm{~Hz}, 5-\mathrm{H}_{B}, 7-\mathrm{H}_{B}\right), 3.71(6 \mathrm{H}, \mathrm{s}, 2 \times \mathrm{OMe}) ; \delta_{\mathrm{C}}(100 \mathrm{MHz}$, $\mathrm{CDCl}_{3}$ ) 56.27, 57.77 (5-C, 7-C), 61.12, 61.17, 109.08 (4-C, 8-C), $122.51,124.12,142.78,152.19,154.15 ; \mathrm{m} / z$ (ES) $425(31 \%$, $\left.M \mathrm{H}^{+}\right), 447\left(4 \%, M \mathrm{Na}^{+}\right), 488\left(100 \%, M \mathrm{Na}_{2} \mathrm{H}_{2} \mathrm{O}^{+}\right) ; R_{f}=0.60$ 
Table 1

Crystallographic data for (8)-(12).

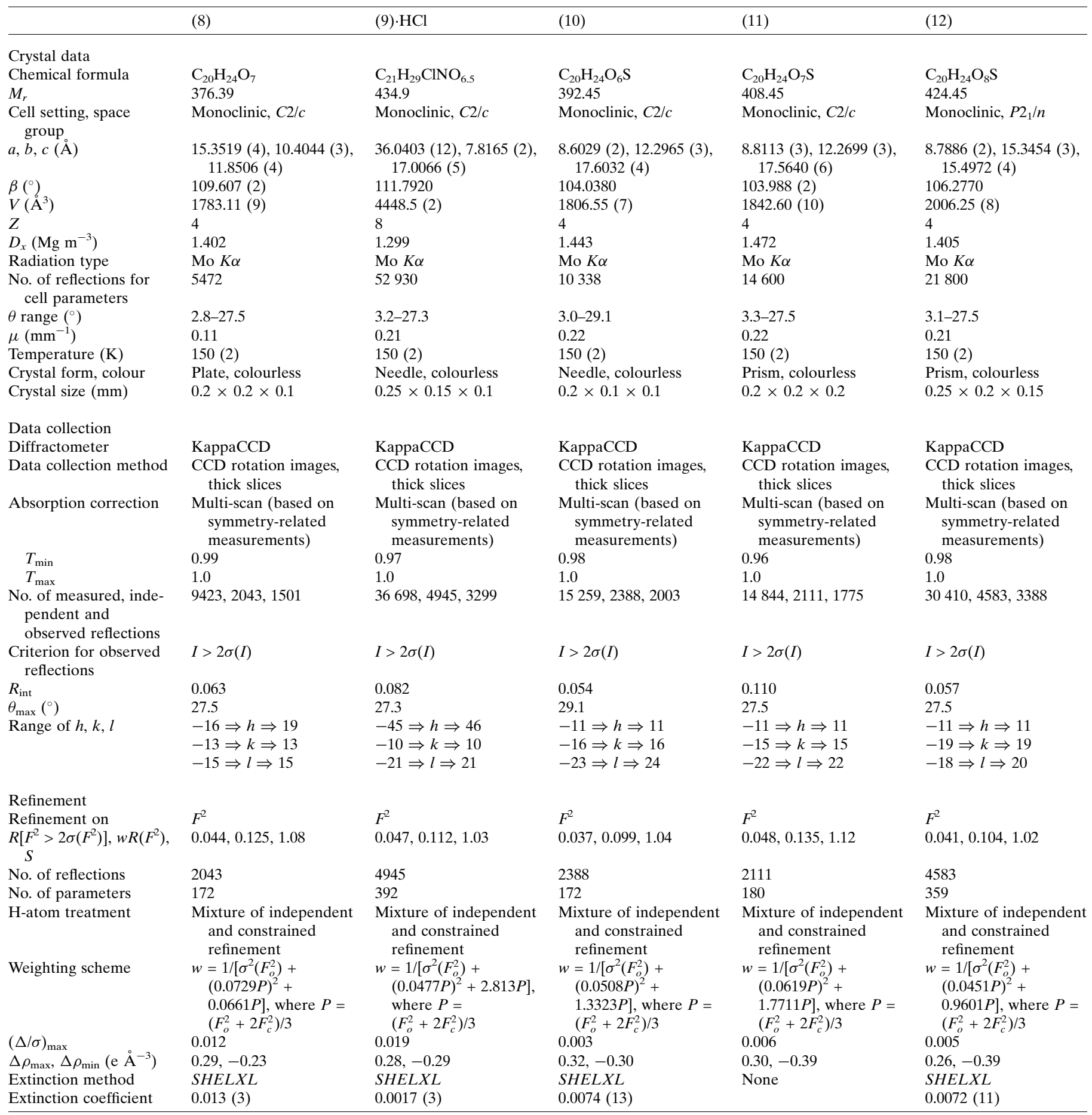

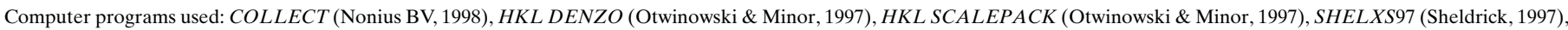
SHELXL97 (Sheldrick, 1997), ORTEP3 for Windows (Farrugia, 1997), WinGX publication routines (Farrugia, 1999).

(EtOAc). Later fractions afforded the title sulfoxide (11) (43 mg, 63\%) as colourless crystals, m.p. $435 \mathrm{~K}$ (EtOAc). Found: C 58.8, $\mathrm{H}$ 6.0, S 7.8; $\mathrm{C}_{20} \mathrm{H}_{24} \mathrm{O}_{7} \mathrm{~S}$ requires $\mathrm{C} 58.81, \mathrm{H}$ $5.92, \mathrm{~S} 7.85 \% ; \delta_{H}\left(400 \mathrm{MHz}, \mathrm{CDCl}_{3}\right) 6.72(1 \mathrm{H}, \mathrm{s}, 4-\mathrm{H}$ or $8-\mathrm{H})$, $6.66(1 \mathrm{H}, \mathrm{s}, 8-\mathrm{H}$ or $4-\mathrm{H}), 4.13(1 \mathrm{H}, \mathrm{d}, J=12.0 \mathrm{~Hz}, 5-\mathrm{H}$ or $7-\mathrm{H})$, 3.93 ( $3 \mathrm{H}, \mathrm{s}, \mathrm{OMe}), 3.91$ (3H, s, OMe), 3.905 (3H, s, OMe), 3.90 $(3 \mathrm{H}, \mathrm{s}, \mathrm{OMe}), 3.74(3 \mathrm{H}, \mathrm{s}, \mathrm{OMe}), 3.71(3 \mathrm{H}, \mathrm{s}, \mathrm{OMe}), 3.68(1 \mathrm{H}$, $\mathrm{d}, J=14.0 \mathrm{~Hz}, 5-\mathrm{H}$ or $7-\mathrm{H}), 3.40(1 \mathrm{H}, \mathrm{d}, J=14.0 \mathrm{~Hz}, 5-\mathrm{H}$ or $7-$ $\mathrm{H}), 3.17(1 \mathrm{H}, \mathrm{d}, J=12.0 \mathrm{~Hz}, 5-\mathrm{H}$ or $7-\mathrm{H}) ; \delta_{\mathrm{C}}\left(75 \mathrm{MHz}, \mathrm{CDCl}_{3}\right)$ 53.88, 55.97 (5-C, 7-C), 56.20, 56.28, 61.00, 61.03, 61.05, 61.12 $\left(6 \times \mathrm{OCH}_{3}\right), 108.45,110.12$ (4-C, 8-C), 122.28, 122.38, 123.90, 125.43 (4a-C, 7a-C, 11a-C and 11b-C), 142.52, 142.98, 151.82, $152.39,153.23,153.41\left(6 \times \mathrm{OC}_{\mathrm{Ar}}\right) ; v_{\max }\left(\mathrm{cm}^{-1}\right) 2944,2839$, 1596, 1577, 1487, 1464, 1406, 1328, 1243, 1200, 1130, 1099, 1041; 
Table 2

Selected interatomic distances $(\AA)$ for $(8)-(12)$.

Here and in other tables, standard uncertainties are given in parentheses for individual results obtained in this work; values in italics are those derived using symmetry transformations to generate equivalent atoms.

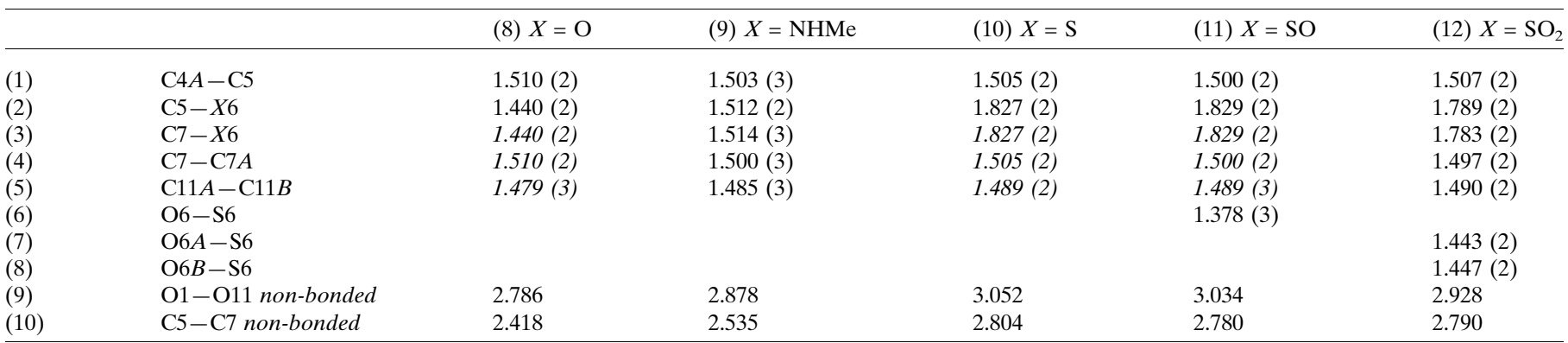<smiles></smiles>

(13)

\section{(a)}<smiles>COC(=O)c1cc(OC)c(OC)c(OC)c1-c1c(OC)c(OC)cc(OC)c1OC</smiles>

(14)<smiles>[R]Cc1cc(OC)c(OC)c(OC)c1-c1c(C[R])cc(OC)c(OC)c1OC</smiles>

(c)

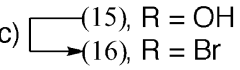<smiles>[X]Cc1cc(OC)c(OC)c(OC)c1-c1c(C)cc(OC)c(OC)c1OC</smiles>

$( \pm)-(8), X=O$

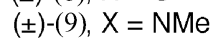
$( \pm)-(10), X=S$

(g)

$\longrightarrow( \pm)-(11), X=\mathrm{SO}$
$\longrightarrow( \pm)-(12), X=\mathrm{SO}_{2}$

Figure 2

Synthesis of compounds (8)-(12). Reagents and conditions: (a) $\mathrm{Me}_{2} \mathrm{SO}_{4}, \mathrm{Bu}_{4} \mathrm{NI}, \mathrm{KOH}$, then $\mathrm{NaH}, \mathrm{DMF}, \mathrm{MeI}(38 \%$ over two steps). (b) LiAlH 4 , THF (91\%). (c) $\mathrm{PBr}_{3}$, ether. (d), $2 \mathrm{M}$ aq. HCl-THF (1:1), heat [93\% (8) from (15)]. (e) $\mathrm{MeNH}_{2}[64 \%$ (9) over two steps via (16)]. (f) Na $\mathrm{S}$ [87\% (10) over two steps via (16)]. (g) mCPBA [60\% (11), 26\% (12)].

$m / z(\mathrm{ES}) 409\left(34 \%, M \mathrm{H}^{+}\right), 431\left(4 \%, M \mathrm{Na}^{+}\right), 472(100 \%$, $\left.M \mathrm{Na}_{2} \mathrm{H}_{2} \mathrm{O}^{+}\right) ; R_{f}=0.20($ EtOAc).

\subsection{X-ray crystallography}

All measurements were carried out using a Nonius KappaCCD diffractometer with graphite-monochromated Mo $K \alpha$ radiation $(\lambda=0.71073 \AA)$. Details of cell parameters, data collection and refinement are summarized in Table 1, together with a list of software employed. The structures were solved by direct methods and refined with all data on $F^{2}$. A weighting scheme based on $P=\left[F_{o}^{2}+2 F_{c}^{2}\right] / 3$ was employed in order to reduce statistical bias (Wilson, 1976). The $\mathrm{H}$ atoms were isotropically refined. ${ }^{\mathbf{1}}$

\section{Results and discussion}

\subsection{Synthesis}

A convenient starting point for the preparation of the bridged systems (8)-(12) is the commercially available tannin

\footnotetext{
${ }^{1}$ Supplementary data for this paper are available from the IUCr electronic archives (Reference: SX5028). Services for accessing these data are described at the back of the journal.
}

ellagic acid (13), which can be polymethylated to obtain the hexamethoxydiphenate (14) (Itoh et al., 1996). The reduction of (14) to the diol (15) and subsequent acid-induced cyclization to (8) were achieved using the published methods (Insole, $1990 a, b)$. The preparation of (9) and (10) also followed conventional routes, the diol (15) being converted into the corresponding bis(bromomethyl)biaryl (16) which was then treated with methylamine to obtain (9) or sodium sulfide to obtain (10). Oxidation of (10) with $m$-chloroperbenzoic acid gave a mixture from which the sulfoxide (11) and sulfone (12) were isolated by chromatography (see Fig. 2).

\subsection{X -ray crystal structures}

The synthesized biaryls all formed crystals which were suitable for analysis by X-ray diffraction. A numbering guide and the derived structures are shown in Figures 3-8, with selected molecular parameters provided in Tables 2 and 3 . Each system crystallized in a monoclinic space group with both enantiomeric forms in the unit cell. The azepine (9) (as the hydrochloride) crystallized with one molecule of water associated with each molecular pair. The oxepine (8), thiepine (10) and sulfoxide (11) exhibit $C_{2}$ molecular symmetry, with the $\mathrm{C} 1$ and $\mathrm{C} 2$ methoxyl groups in a mutually eclipsed 
Table 3

Selected bond and dihedral angles $\left(^{\circ}\right)$ for (8)-(12).

\begin{tabular}{|c|c|c|c|c|c|c|}
\hline & & (8) $X=\mathrm{O}$ & (9) $X=$ NHMe & (10) $X=\mathrm{S}$ & (11) $X=\mathrm{SO}$ & (12) $X=\mathrm{SO}_{2}$ \\
\hline (1) & $\mathrm{C} 5-X 6-\mathrm{C} 7$ & $114.2(2)$ & $113.9(2)$ & $100.3(1)$ & $98.9(2)$ & $102.7(1)$ \\
\hline (2) & $\mathrm{C} 5-\mathrm{C} 4 A-\mathrm{C} 11 B-\mathrm{C} 11 A$ & $0.8(2)$ & $7.7(3)$ & $1.4(2)$ & $0.9(3)$ & $0.8(3)$ \\
\hline (3) & $\mathrm{C} 4 A-\mathrm{C} 5-X 6-\mathrm{C} 7$ & $-43.6(1)$ & $-50.4(2)$ & $-44.5(1)$ & $-45.0(1)$ & $-44.6(2)$ \\
\hline (4) & $\mathrm{C} 7 A-\mathrm{C} 7-X 6-\mathrm{C} 5$ & $-43.6(1)$ & $-35.2(2)$ & $-44.5(1)$ & $-45.0(1)$ & $-44.4(2)$ \\
\hline (5) & $\mathrm{C} 7-\mathrm{C} 7 A-\mathrm{C} 11 A-\mathrm{C} 11 B$ & $0.8(2)$ & $-6.7(3)$ & $1.4(2)$ & $0.9(3)$ & $-6.0(2)$ \\
\hline (6) & $\mathrm{C} 7 A-\mathrm{C} 11 A-\mathrm{C} 11 B-\mathrm{C} 4 A$ & $-49.8(3)$ & $-51.1(3)$ & $-59.9(3)$ & $-58.8(3)$ & $-54.9(2)$ \\
\hline (7) & $\mathrm{C} 11-\mathrm{C} 11 A-\mathrm{C} 11 B-\mathrm{C} 1$ & $-57.0(3)$ & $-53.6(3)$ & $-61.9(3)$ & $-63.6(3)$ & $-61.4(2)$ \\
\hline (8) & $\mathrm{C} 11-\mathrm{C} 11 A-\mathrm{C} 11 B-\mathrm{C} 4 \mathrm{~A}$ & $126.6(3)$ & $121.7(2)$ & $119.0(3)$ & $118.8(3)$ & $122.1(2)$ \\
\hline (9) & $\mathrm{C} 7 A-\mathrm{C} 11 A-\mathrm{C} 11 B-\mathrm{C} 1$ & $126.6(3)$ & $133.6(2)$ & $119.0(3)$ & $118.8(3)$ & $121.5(2)$ \\
\hline (10) & $\mathrm{O} 1-\mathrm{C} 1-\mathrm{C} 2-\mathrm{O} 2$ & $4.2(2)$ & $6.5(3)$ & $4.5(2)$ & $4.9(2)$ & $3.4(2)$ \\
\hline (11) & $\mathrm{O} 1-\mathrm{C} 1-\mathrm{C} 2-\mathrm{C} 3$ & $179.3(2)$ & $-175.1(2)$ & $-178.7(2)$ & $-179.2(2)$ & $-177.1(2)$ \\
\hline (12) & $\mathrm{O} 1-\mathrm{C} 1-\mathrm{C} 11 B-\mathrm{C} 4 A$ & $176.3(2)$ & $170.0(2)$ & $177.2(2)$ & $176.9(2)$ & $173.7(2)$ \\
\hline (13) & $\mathrm{O} 1-\mathrm{C} 1-\mathrm{C} 11 B-\mathrm{C} 11 \mathrm{~A}$ & $-0.1(2)$ & $-14.8(3)$ & $-1.9(2)$ & $-0.7(3)$ & $-2.8(2)$ \\
\hline (14) & $\mathrm{O} 2-\mathrm{C} 2-\mathrm{C} 3-\mathrm{O} 3$ & $0.4(2)$ & $1.0(2)$ & $-3.9(2)$ & $-4.1(3)$ & $1.3(2)$ \\
\hline (15) & $\mathrm{O} 3-\mathrm{C} 3-\mathrm{C} 4-\mathrm{C} 4 A$ & $174.1(2)$ & $178.1(2)$ & $-179.5(2)$ & $-179.5(2)$ & $-179.5(2)$ \\
\hline (16) & $\mathrm{O} 3-\mathrm{C} 3-\mathrm{C} 2-\mathrm{C} 1$ & $-174.7(2)$ & $-177.4(2)$ & $179.3(2)$ & $-179.8(2)$ & $-178.3(2)$ \\
\hline (17) & $\mathrm{O} 11-\mathrm{C} 11-\mathrm{C} 10-\mathrm{O} 10$ & $4.2(2)$ & $-1.1(3)$ & $4.5(2)$ & $4.9(2)$ & $0.3(3)$ \\
\hline (18) & $\mathrm{O} 10-\mathrm{C} 10-\mathrm{C} 9-\mathrm{O} 9$ & $0.4(2)$ & $3.1(3)$ & $-3.9(2)$ & $-4.1(3)$ & $1.4(3)$ \\
\hline (19) & $\mathrm{C} 1-\mathrm{C} 2-\mathrm{C} 3-\mathrm{C} 4$ & $3.6(2)$ & $5.2(3)$ & $0.4(2)$ & $1.6(3)$ & $3.6(3)$ \\
\hline (20) & $\mathrm{C} 2-\mathrm{C} 3-\mathrm{C} 4-\mathrm{C} 4 A$ & $-4.0(2)$ & $-4.7(3)$ & $-0.7(2)$ & $-1.1(3)$ & $-1.6(3)$ \\
\hline (21) & $\mathrm{C} 3-\mathrm{C} 4-\mathrm{C} 4 A-\mathrm{C} 11 B$ & $-0.4(2)$ & $-0.8(3)$ & $-0.9(2)$ & $-1.2(3)$ & $-2.0(3)$ \\
\hline (22) & $\mathrm{C} 4-\mathrm{C} 4 A-\mathrm{C} 11 B-\mathrm{C} 1$ & $5.1(2)$ & $5.8(3)$ & $2.7(2)$ & $2.9(3)$ & $3.5(3)$ \\
\hline (23) & $\mathrm{C} 4 A-\mathrm{C} 11 B-\mathrm{C} 1-\mathrm{C} 2$ & $-5.5(2)$ & $-5.3(3)$ & $-3.1(2)$ & $-2.4(3)$ & $-1.5(3)$ \\
\hline (24) & $\mathrm{C} 11 B-\mathrm{C} 1-\mathrm{C} 2-\mathrm{C} 3$ & $1.2(2)$ & $-0.1(3)$ & $1.5(2)$ & $0.1(3)$ & $-2.1(3)$ \\
\hline (25) & $\mathrm{C} 11-\mathrm{C} 10-\mathrm{C} 9-\mathrm{C} 8$ & $3.6(2)$ & $1.1(3)$ & $0.4(2)$ & $1.6(3)$ & $-2.7(3)$ \\
\hline (26) & $\mathrm{C} 10-\mathrm{C} 9-\mathrm{C} 8-\mathrm{C} 7 A$ & $-4.0(2)$ & $-1.9(3)$ & $-0.7(2)$ & $-1.1(3)$ & $0.3(3)$ \\
\hline (27) & $\mathrm{C} 9-\mathrm{C} 8-\mathrm{C} 7 A-\mathrm{C} 11 A$ & $-0.4(2)$ & $0.1(3)$ & $-0.9(2)$ & $-1.2(3)$ & $2.5(3)$ \\
\hline (28) & $\mathrm{C} 8-\mathrm{C} 7 A-\mathrm{C} 11 A-\mathrm{C} 11$ & $5.1(2)$ & $2.4(3)$ & $2.7(2)$ & $2.9(3)$ & $-2.8(3)$ \\
\hline (29) & $\mathrm{C} 7 A-\mathrm{C} 11 A-\mathrm{C} 11-\mathrm{C} 10$ & $-5.5(2)$ & $-3.2(3)$ & $-3.1(2)$ & $-2.4(3)$ & $0.3(3)$ \\
\hline (30) & $\mathrm{C} 11 A-\mathrm{C} 11-\mathrm{C} 10-\mathrm{C} 9$ & $1.2(2)$ & $1.5(3)$ & $1.5(2)$ & $0.1(3)$ & $2.4(3)$ \\
\hline (31) & $\mathrm{C} 8-\mathrm{C} 7 A-\mathrm{C} 11 A-\mathrm{C} 11 B$ & $-178.4(2)$ & $175.4(2)$ & $-178.2(1)$ & $-179.4(2)$ & $174.4(2)$ \\
\hline (32) & $\mathrm{C} 10-\mathrm{C} 11-\mathrm{C} 11 A-\mathrm{C} 11 B$ & $178.1(1)$ & $-176.3(2)$ & $177.9(1)$ & $180.0(2)$ & $-176.8(2)$ \\
\hline (33) & $\mathrm{C} 4-\mathrm{C} 4 A-\mathrm{C} 11 B-\mathrm{C} 11 A$ & $-178.4(2)$ & $-169.6(2)$ & $-178.2(1)$ & $-179.4(2)$ & $179.9(2)$ \\
\hline (34) & $\mathrm{C} 2-\mathrm{C} 1-\mathrm{C} 11 B-\mathrm{C} 11 A$ & $178.1(1)$ & $170.0(2)$ & $177.9(1)$ & $180.0(2)$ & $-178.0(2)$ \\
\hline
\end{tabular}

arrangement which is replicated at $\mathrm{C} 11$ and $\mathrm{C} 10$. In the sulfone (12) the corresponding methoxyl groups are splayed apart in arrangements which differ with respect to the aromatic rings, although the seven-membered ring effectively retains local $C_{2}$ symmetry. The azepinium salt (9) $\cdot \mathrm{HCl}$ differs significantly from the other structures in that not only are the methoxyl groups arranged differently in each aromatic ring, but the seven-membered ring no longer possesses local $C_{2}$ symmetry and the $\mathrm{C} 1-\mathrm{C} 11 B$ aromatic ring is displaced from the expected plane. These features are discussed in detail below.

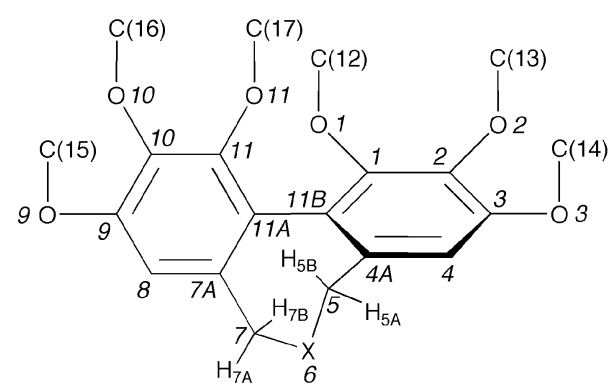

Figure 3

The numbering system for the structures in Figs. 4-8, which were all generated with $\mathrm{C} 7 A, \mathrm{C} 11 A$ and $\mathrm{C} 11 B$ in the viewed plane and the $\mathrm{C} 11 A-\mathrm{C} 11 B$ bond aligned horizontally.
The structure of the sulfoxide (11) is disordered in that, while the position of the S atom is fixed, the attached $\mathrm{O} 6$ atom is distributed equally between the two possible locations. The ${ }^{1} \mathrm{H}$ NMR spectrum of (11) also reflects its distinctive symmetry properties. Although the $\mathrm{S}$ atom is not a stereogenic centre, the combined presence of the stereogenic axis and the single O6 atom renders the C5 and C7 methylene groups nonequivalent and diastereotopic. Each of these four $\mathrm{H}$ atoms thus appears as an individual doublet in the ${ }^{1} \mathrm{H}$ NMR spec-

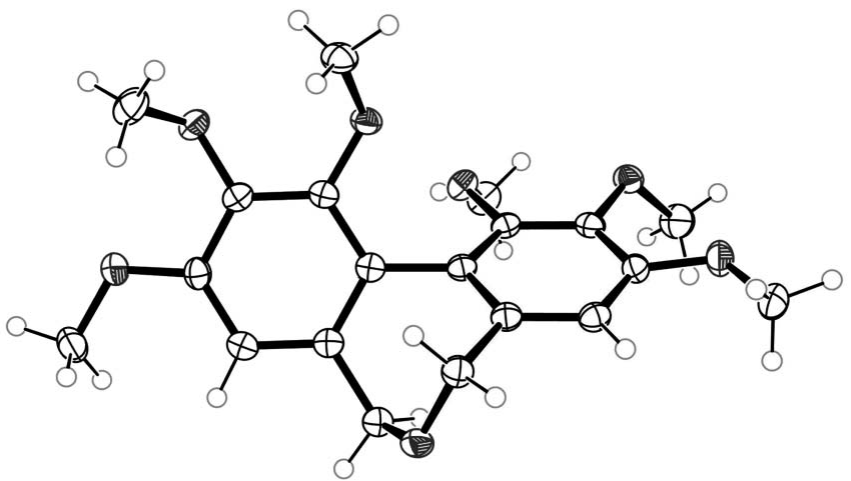

Figure 4

5,7-Dihydro-1,2,3,9,10,11-hexamethoxydibenzo[c,e]oxepine (8). Displacement ellipsoids in Figs. $4-8$ are drawn at the $50 \%$ probability level. 
trum of (11), as has been described for a related system (Fraser \& Schuber, 1970).

For the reasons outlined above, our interest in structures (8)-(12) is centred on the helicity of the respective biaryl moieties, which is viewed in Fig. 9. In each case the sevenmembered ring has taken up a helical conformation in which the flexibility of the biaryl axis must be subject to upper and lower limits dictated by the geometric constraints of the threeatom bridge and the interaction of the 1- and 11-substituents, which are obliged to move towards each other if the system moves towards planarity. It is therefore pertinent to examine four sets of parameters, viz. the $\mathrm{C}-X$ bond lengths (Table 2, rows 2,3), the $\mathrm{O} 1-\mathrm{O} 11$ distances (Table 2, row 9), the endocyclic biaryl dihedral angles (Table 3, row 6) and the exocyclic biaryl dihedral angles (Table 3, row 7). From a comparison of the $\mathrm{C}-X$ bond lengths with the biaryl dihedral angles through the series it is evident that the more pronounced helicity of the thiepines (10)-(12) is primarily a consequence of the seven-membered ring twisting more in order to accommodate the longer $\mathrm{C}-\mathrm{S}$ bonds; the smaller $\mathrm{C}-$ $\mathrm{S}-\mathrm{C}$ bond angles (Table 3, row 1 ) will counteract this effect slightly. The oxepine (8) and azepinium chloride (9) $\cdot \mathrm{HCl}$, with their shorter $\mathrm{C}-X$ bonds, exhibit degrees of twist some $10^{\circ}$ lower than observed in the sulfur series.

It is notable that in each of the structures (8)-(12) the endocyclic and exocyclic dihedral angles are unequal, the latter invariably exceeding the former, and that neither series runs entirely in parallel with the $\mathrm{C}-X$ bond length. In a nonbridged biphenyl with perfectly planar trigonal $\mathrm{C}$ atoms the two biaryl dihedral angles should be equal, so the difference between them in a bridged structure might be viewed as an indicator of the distortion around the biaryl axis. In the systems (8)-(12) this difference would be expected to arise from steric repulsion between the 1- and 11-methoxyl groups, which operates on the exocyclic quadrants of the biaryl axis and opposes the constraining effect of the three-atom bridge. The close proximity of these methoxyl groups is evident in the O1-O11 distance (Table 2, row 9), which reaches twice the van der Waals radius for oxygen, $1.52 \AA$ (Bondi, 1964; Bott et al., 1980), only in the cases of (10) and (11). This steric

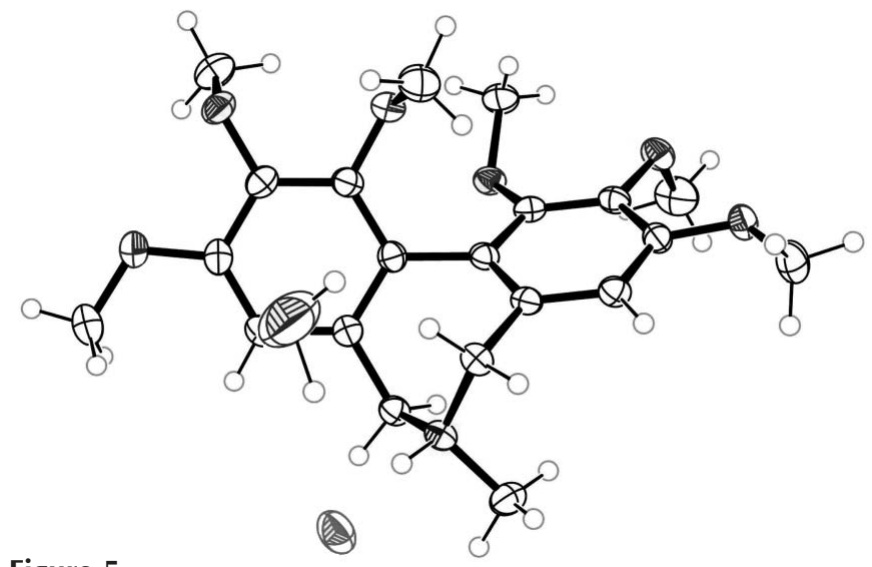

Figure 5

6,7-Dihydro-1,2,3,9,10,11-hexamethoxy-6-methyl-5H-dibenzo[c,e]azepinium chloride (9) $\cdot \mathrm{HCl}$ hemihydrate. compression, reinforced by the buttressing effect of the adjacent methoxyl groups (Insole, 1990a,b; Charton, 1977), is maximal in the oxepine (8) and would account, at least in part, for the relatively large $\left(7.2^{\circ}\right)$ difference between the endocyclic and exocyclic dihedral angles in this structure and for the dihedral angles of more than $5^{\circ}$ associated with $\mathrm{C} 1, \mathrm{C} 11 B$ and $\mathrm{C} 4 A$ (Table 3, rows 22, 23), through which its levering effects are dissipated. By the dihedral angle criterion the thiepine (10) incorporates a much less distorted biaryl axis, consistent with the longer $\mathrm{C}-\mathrm{S}$ bonds inducing a more pronounced twist in the seven-membered ring and, as a consequence, alleviating the steric interaction between $\mathrm{O} 1$ and O11. The structural parameters for the sulfoxide (11) are very similar to those of the thiepine (10), but the difference between the endocyclic and exocyclic dihedral angles rises from 2.0 to $4.8^{\circ}$. The sulfone (12) manifests rather more distortion at the biaryl axis than the other thiepine derivatives, the dihedral angle difference now being $6.5^{\circ}$. The reduced endocyclic dihedral angle in (12) [by $5^{\circ}$ compared with the thiepine (10)] is consistent with its shorter $\mathrm{C}-\mathrm{S}$ bonds (Table 2 , rows 2,3 ), but the flattening in the seven-membered ring is not reciprocated in the exocyclic region, where the dihedral angle remains above $61^{\circ}$ even though the $\mathrm{O} 1-\mathrm{O} 11$ distance (Table 2, row 9) shortens significantly. The extent to which

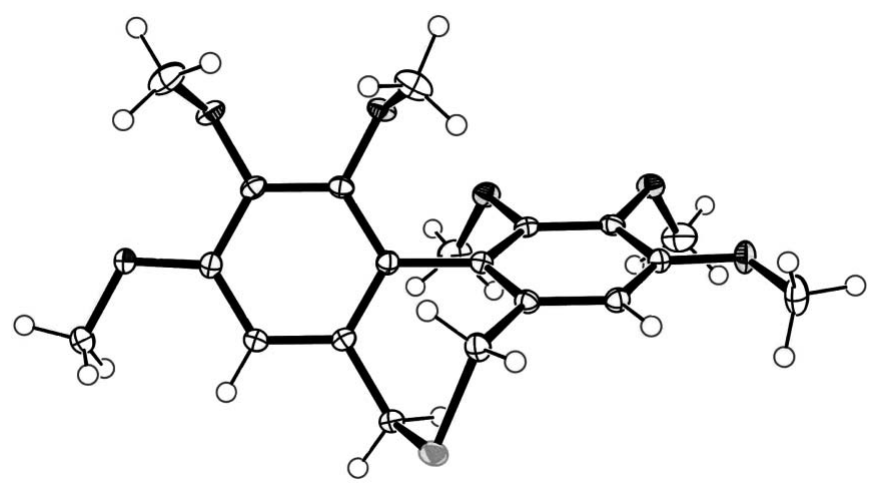

Figure 6

5,7-Dihydro-1,2,3,9,10,11-hexamethoxydibenzo[c,e]thiepine (10).

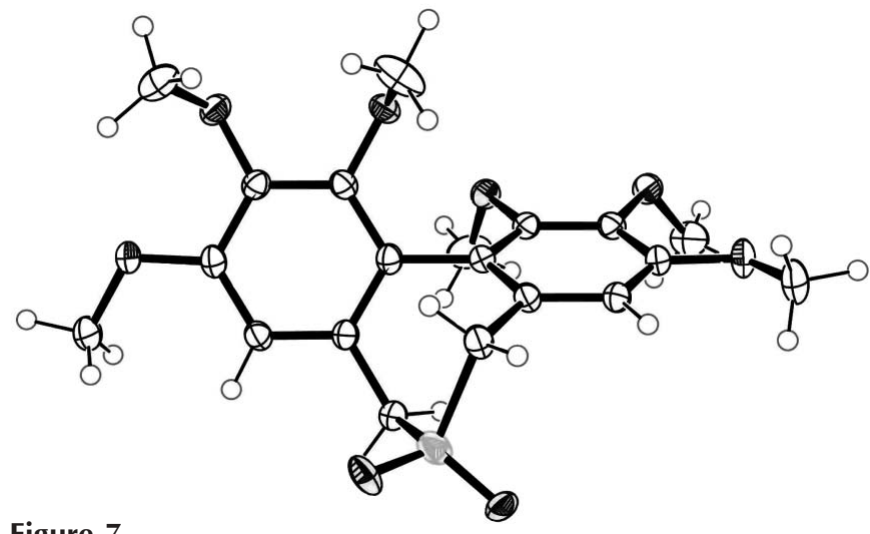

Figure 7

5,7-Dihydro-1,2,3,9,10,11-hexamethoxydibenzo[c,e]thiepine 6-oxide (11). 
intermolecular (crystal packing) effects might contribute to these structural features of (12) is discussed later.

In the case of the azepinium salt (9). $\mathrm{HCl}$ the relatively small difference between the biaryl endocyclic and exocyclic dihedral angles $\left(2.5^{\circ}\right)$ is not a useful guide to the forces operating in this region of the molecule. The $\mathrm{C} 1-\mathrm{C} 2$ and $\mathrm{C} 4 A-\mathrm{C} 4$ bonds are both $10^{\circ}$ out of alignment with the inter-aryl bond (Table 3, rows 33, 34), as is perceptible in Fig. 9. The dihedral angles of more than $5^{\circ}$ around $\mathrm{C} 1, \mathrm{C} 11 B$ and $\mathrm{C} 4 A$ (Table 3, rows 22,23$)$ are consistent with the effects of 1,11-methoxyl repulsion, as observed in the oxepine (8), but there is also a twisting of the seven-membered ring, unique in the series and manifested by a difference of $15^{\circ}$ in the dihedral angles spanning the endocyclic $\mathrm{C}-\mathrm{N}$ bonds (Table 3 , rows 3,4 ) and $12^{\circ}$ in those spanning the two aryl rings (Table 3 , rows 8,9 ). The ultimate origins of the distortion in the crystal structure of (9) $\cdot \mathrm{HCl}$ are obscure, although the association of the chloride ion with one face of the seven-membered ring is a potentially significant desymmetrizing factor.

To broaden this analysis, the ConQuest software (Allen, 2002; Bruno et al., 2002) was used to search the Cambridge Structural Database for substructures containing a 1,1'-biaryl with a 2,2'-bridge of the form $\mathrm{CH}_{2} X \mathrm{CH}_{2}$, where $X=\mathrm{O}, \mathrm{N}$ or S, and most of the structures recovered are listed in Fig. 10 in order of increasing endocyclic dihedral angle for each heteroatom series. In the oxygen series the endocyclic biaryl

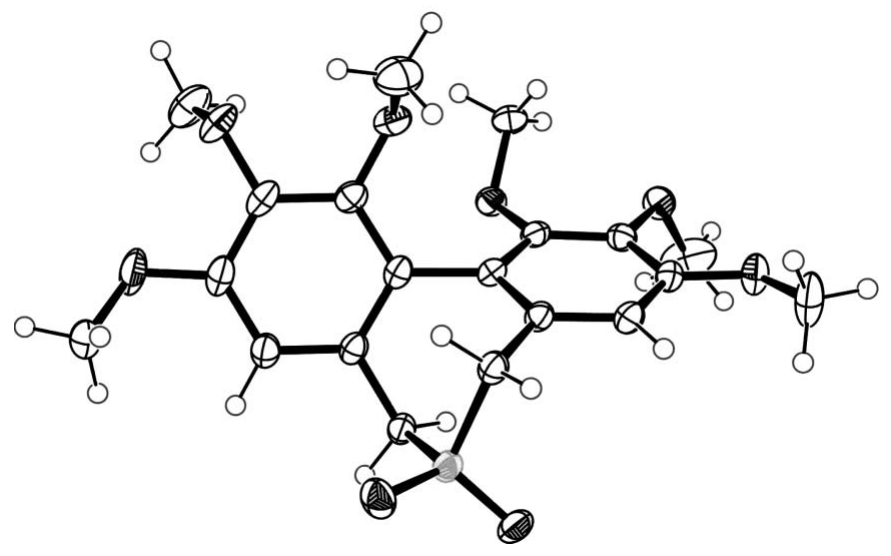

Figure 8

5,7-Dihydro-1,2,3,9,10,11-hexamethoxydibenzo[c,e]thiepine $\quad 6,6$-dioxide (12). dihedral angles vary over more than $18^{\circ}$ in going from the parent system present in (17) to the bis(phosphine) (20). Throughout this series the exocyclic dihedral angle remains responsive to the steric size of the 6- and 6'-substituents, increases in the exocyclic dihedral angle being possible through bending processes, whereas the endocyclic dihedral angle is constrained by bond-length requirements.

A similar trend is seen in the nitrogen series, where the endocyclic dihedral angle does not exceed $55.0^{\circ}$, while the exocyclic dihedral angle is forced up by bulky ortho groups and reaches $67.8^{\circ}$ in the binaphthyl (29). The underlying flexibility of the biaryl system can be seen in the variation, by $5^{\circ}$ or more, of the respective dihedral angles in analogous molecules, e.g. (21) and (22) or (24) and (29). In the sulfur series the longer $(\mathrm{C}-\mathrm{S})$ bonds in the seven-membered ring permit larger endocyclic dihedral angles and a framework capable of accommodating larger ortho-substituents (Me, naphthyl) with minimal distortion at the axis. Axial flexibility is illustrated in the thiepine series by (30) and (31), whose respective unit cells contain three or more equivalent biaryl axes with varying dihedral angles.

The distinction between the geometry of a molecule in the crystalline state, where it is subject to intermolecular (crystal packing) forces, and its conformation in solution is of fundamental importance in the context of biological effects. The crystal structure dihedral angles for the tubulin binding agents colchicine (1) (Lessinger \& Margulis, 1978) and $N$-acetylcolchinol (3) (Margulis \& Lessinger, 1978) are shown in Fig. 11. Although the multiple dihedral angles for (3) reveal some flexibility in its biaryl axis, each of these structures crystallizes as a hydrated system with a packing arrangement involving complex hydrogen bonding. The situation is simpler in the cases of the oxepine (8) and sulfone (12), and it was considered that computational modelling of these molecules might provide a means of estimating the contribution made by crystal packing effects to their solid-state structures. Accordingly, the structures (8) and (12) were allowed to 'relax' by using semi-empirical (force field) methods to minimize their steric energies, starting from the atomic coordinates provided by X-ray crystallography. The minimized structures $\left(8^{\prime}\right)$ and $\left(12^{\prime}\right)$ indicate less distortion in the region of the biaryl axis, primarily through a reduced exocyclic biaryl dihedral angle in $\left(8^{\prime}\right)$ and an increased endocyclic dihedral angle in $\left(12^{\prime}\right)$ (Fig.

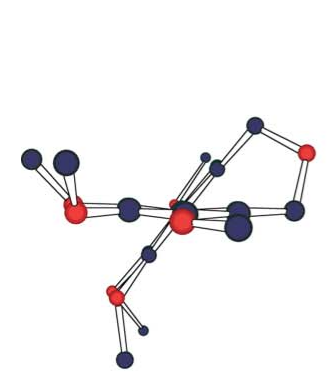

(8)

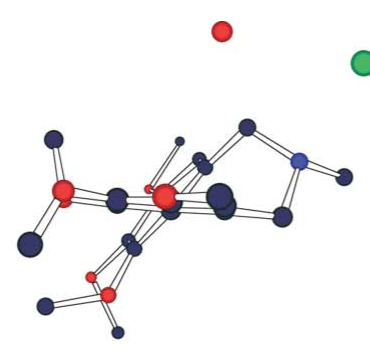

$(9) \cdot \mathrm{HCl}$

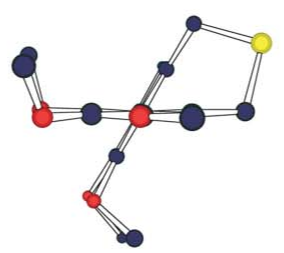

(10)

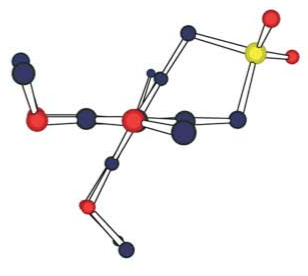

(11)

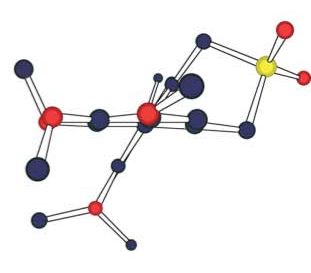

(12)

Figure 9

Views of (8)-(12) along the $\mathrm{C} 11 A-\mathrm{C} 11 B$ bond. The plane defined by $\mathrm{C} 7 A, \mathrm{C} 11 A$ and $\mathrm{C} 11 B$ is perpendicular to the viewed plane. $\mathrm{H}$ atoms are omitted. 
11), the inference being that these parameters are particularly affected by crystal packing forces within the respective solidstate structures. However, while the geometries of the energyminimized structures may be more representative of the dominant solution conformations of such molecules, it can be speculated that the conformational flexibility of the bridged biaryl unit, implicit in the results reported here and in the Xray diffraction data cited, is a more significant factor in the large number of colchicine analogues that retain the tubulinbinding capability of the natural product.

\section{Conclusions}

The biaryls (8), (9). $\mathrm{HCl},(10),(11)$ and (12), each incorporating a three-atom bridge of the form $\mathrm{CH}_{2}-X-\mathrm{CH}_{2}(X=\mathrm{O}$, $\mathrm{N}$ or S), have been characterized by X-ray crystal structure analysis. Within this series the endocyclic and exocyclic biaryl dihedral angles vary over slightly offset but roughly parallel $10^{\circ}$ ranges in a manner which is consistent with each structure being subject to a variable blend of intramolecular (steric, geometric) and intermolecular (crystal packing) forces of

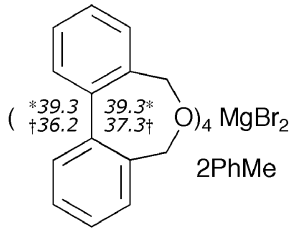

(17)

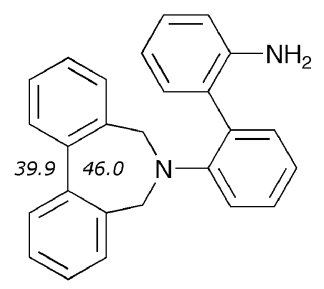

(22)

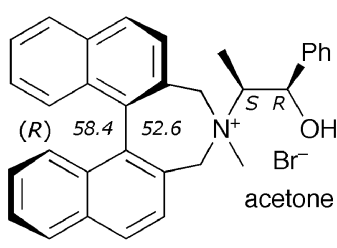

(26)

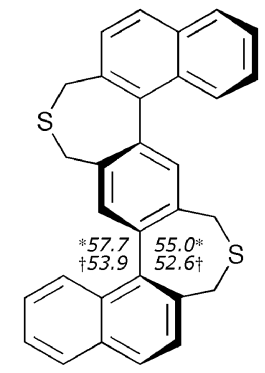

(30)

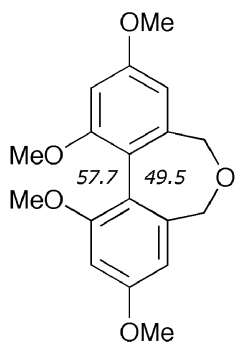

(18)

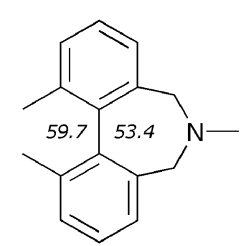

(23)

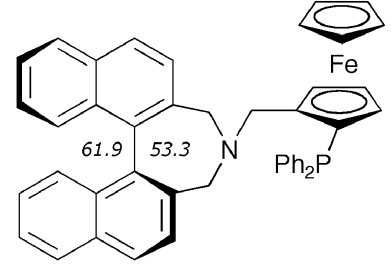

(27)<smiles>Cc1cc([N+](=O)[O-])cc2c1-c1c(C)cc([N+](=O)[O-])cc1COC2</smiles>

(19)

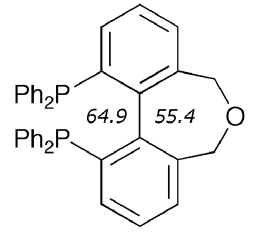

(20)

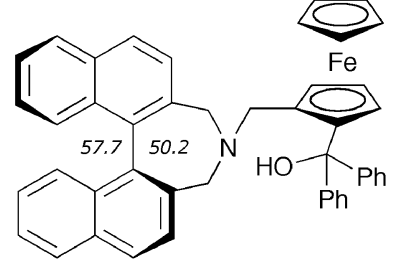

(24)

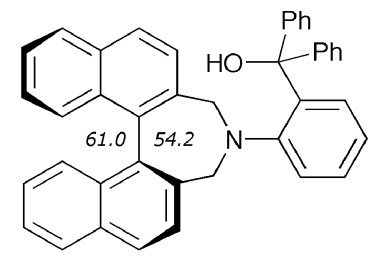

(28)

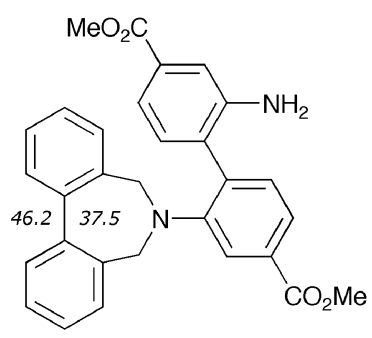

(21)

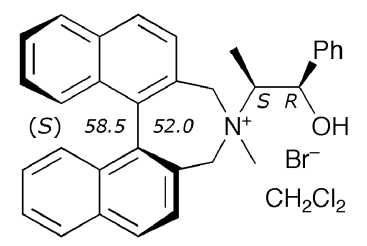

(25)

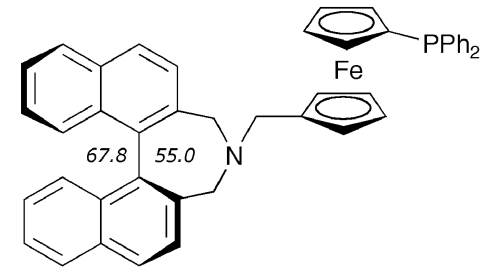

(29)

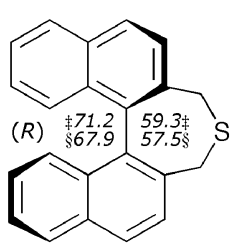

(31)

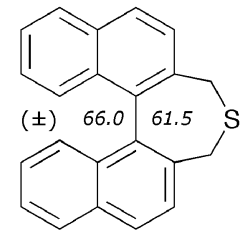

(32)

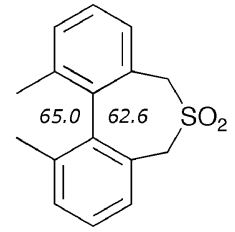

(33)

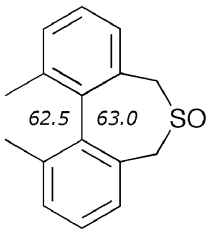

(34)

Figure 10

Dihedral angles $\left({ }^{\circ}\right)$ around the aryl-aryl bond in biaryl-fused oxepines, azepines and thiepines (taken from published X-ray data). The numerical values of the exocyclic and endocyclic biaryl dihedral angles are indicated. Symbols: $(*)$ highest of four per unit cell; ( $\dagger)$ lowest of four per unit cell; ( $\ddagger)$ highest of three per unit cell; (§) lowest of three per unit cell; $(\boldsymbol{\Phi})$ highest of two per unit cell; (¥) lowest of two per unit cell. CSD six-letter codes: (17), DIFTAN (Engelhardt et al., 1985); (18), JAFLAE (Bringmann et al., 2003); (19), TICTOO (Roszak et al., 1996); (20), GEDYOD (Schmid et al., 1988); (21), GAVKET (Nyburg et al., 1988); (22), GAVKAP (Nyburg et al., 1988); (23), NUBGOG (Mrvoš-Sermek et al., 1998); (24), XEBNOH (Arroyo et al., 2000); (25), WOBMIJ (Schneider et al., 2000); (26), WOBMEF (Schneider et al., 2000); (27), HOVGEE (Widhalm et al., 1999); (28), XEBNIB (Arroyo et al., 2000); (29), HOVGOO (Widhalm et al., 1999); (30), SIZQOH (Kiupel et al., 1998); (31), YIPREU01 (Miyake et al., 2002); (32), YIPREU (Bandarage et al., 1995); (33), KIRPOQ (Loncar-Tomascovic et al., 2000); (34), KIRKOL (Loncar-Tomascovic et al., 2000). 

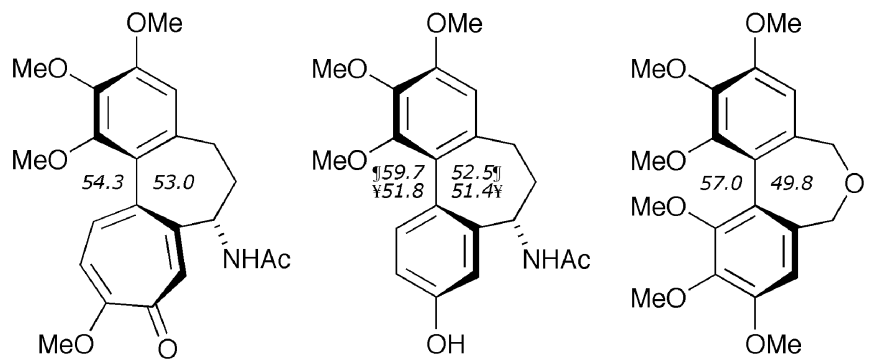

(1) (X-ray)

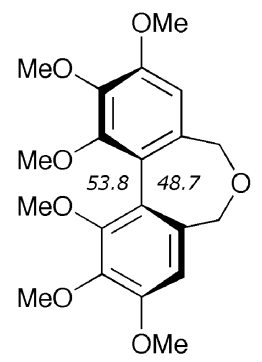

(8') (MM3)

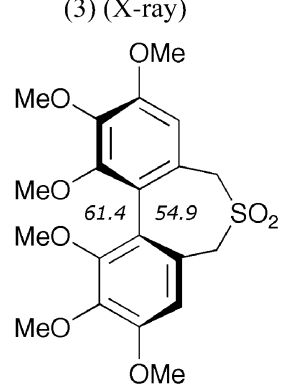

(12) (X-ray)
(8) (X-ray)

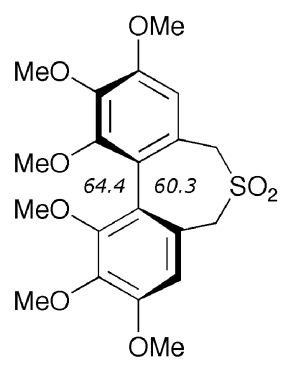

(12') (MM3)

\section{Figure 11}

Dihedral angles $\left(^{\circ}\right)$ around the aryl-aryl bond in (1), (3) (from published X-ray data), $\left(8^{\prime}\right)$ and $\left(12^{\prime}\right)$. To generate $\left(8^{\prime}\right)$ and $\left(12^{\prime}\right)$, models of $(8)$ and (12) were assembled from their crystal structure atom coordinates using Quantum CAChe4.5 (Fujitsu) and their geometries optimized with the Mechanics application using an augmented MM3 force field. The structures $\left(8^{\prime}\right)$ and $\left(12^{\prime}\right)$ are assumed to be nearby (but not necessarily global) steric energy minima. The number inside the seven-membered ring is the $\mathrm{C} 7 A-\mathrm{C} 11 A-\mathrm{C} 11 B-\mathrm{C} 4 A$ dihedral angle; the other number is the $\mathrm{C} 11-\mathrm{C} 11 A-\mathrm{C} 11 B-\mathrm{C} 1$ dihedral angle. Symbols: ( $\mathbf{9})$ highest of the two per unit cell; (¥) lowest of the two per unit cell.

comparable strength. The results are consistent with the expectation that the major determinant of the degree of helicity in the seven-membered ring, and hence in the biaryl chromophore, is the $\mathrm{C}-X$ bond length. The results also suggest that there is a significant degree of conformational flexibility within the biaryl unit, despite the presence of the three-atom bridge.

We thank the Association for International Cancer Research for financial support. We also wish to acknowledge the use of the EPSRC's Chemical Database Service at Daresbury (Fletcher et al., 1996) and of ORTEP3 for Windows for the generation of graphics (Farrugia, 1997).

\section{References}

Allen, F. H. (2002). Acta Cryst. B58, 380-388.

Arroyo, N., Haslinger, U., Mereiter, K. \& Widhalm, M. (2000). Tetrahedron Asym. 11, 4207-4219.

Bandarage, U. K., Hanton, L. R. \& Smith, R. A. J. (1995). Tetrahedron, 51, 787-800.

Banwell, M. G., Cameron, J. M., Corbett, M., Dupuche, J. R., Hamel, E., Lambert, J. N., Lin, C. M. \& Mackay, M. F. (1992). Aust. J. Chem. 45, 1967-1982.

Berg, U. \& Bladh, H. (1999). Helv. Chim. Acta, 82, 323-325.

Bergemann, S., Brecht, R., Büttner, F., Guénard, D., Gust, R., Seitz, G., Stubbs, M. T. \& Thoret, S. (2003). Bioorg. Med. Chem. 11, 12691281.

Bondi, A. (1964). J. Phys. Chem. 68, 441-451.

Bott, G., Field, L. D. \& Sternhell, S. (1980). J. Am. Chem. Soc. 102, $5618-5626$.

Boyé, O. \& Brossi, A. (1992). The Alkaloids, Vol. 41, edited by A. Brossi \& G. A. Cordell, ch. 3. San Diego: Academic Press.

Boyé, O., Getahun, Z., Grover, S., Hamel, E. \& Brossi, A. (1993). J. Labelled Compd. Radiopharm. 33, 293-299.

Boyé, O., Itoh, Y. \& Brossi, A. (1989). Helv. Chim. Acta, 72, 16901696.

Bringmann, G., Pfeifer, R.-M., Rummey, C., Pabst, T., Leusser, D. \& Stalke, D. (2003). Z. Naturforsch. Teil B, 58, 231-236.

Brossi, A. (1990). J. Med. Chem. 33, 2311-2319.

Brossi, A., Boyé, O., Muzaffar, A., Yeh, H. J. C., Toome, V., Wegrzynski, B. \& George, C. (1990). FEBS Lett. 262, 5-7.

Brossi, A., Lee, H.-H. \& Yeh, H. J. C. (1999). Helv. Chim. Acta, 82, 1223-1224.

Bruno, I. J., Cole, J. C., Edgington, P. R., Kessler, M., Macrae, C. F., McCabe, M. P., Pearson, J. \& Taylor, R. (2002). Acta Cryst. B58, 389-397.

Cavazza, M., Zandomeneghi, M. \& Pietra, F. (2000). Tetrahedron Lett. 41, 9129-9133.

Charton, M. (1977). J. Org. Chem. 42, 2528-2529.

Davis, P. D., Dougherty, G. J., Blakey, D. C., Galbraith, S. M., Tozer, G. M., Holder, A. L., Naylor, M. A., Nolan, J., Stratford, M. R. L., Chaplin, D. J. \& Hill, S. A. (2002). Cancer Res. 62, 7247-7253.

Edwards, D. J., Pritchard, R. G. \& Wallace, T. W. (2003). Tetrahedron Lett. 44, 4665-4668.

Engelhardt, L. M., Lueng, W. P., Raston, C. L. \& White, A. H. (1985). Aust. J. Chem. 38, 977-983.

Farrugia, L. J. (1997). J. Appl. Cryst. 30, 565.

Farrugia, L. J. (1999). J. Appl. Cryst. 32, 837-838.

Fletcher, D. A., McMeeking, R. F. \& Parkin, D. (1996). J. Chem. Inf. Comput. Sci. 36, 746-749.

Fraser, R. R. \& Schuber, F. J. (1970). Can. J. Chem. 48, 633-640.

Hall, M. D. (1969). Progress in Stereochemistry, Vol. 4, edited by B. J. Aylett \& M. M. Harris, pp. 1-42. London: Butterworths.

Insole, J. M. (1990a). J. Chem. Res. S, pp. 378-379.

Insole, J. M. (1990b). J. Chem. Res. M, pp. 2831-2867.

Itoh, T., Chika, J.-I., Shirakami, S., Ito, H., Yoshida, T., Kubo, Y. \& Uenishi, J.-I. (1996). J. Org. Chem. 61, 3700-3705.

Janik, M. E. \& Bane, S. L. (2002). Bioorg. Med. Chem. 10, 1895-1903.

Kang, G. J., Getahun, Z., Muzaffar, A., Brossi, A. \& Hamel, E. (1990). J. Biol. Chem. 265, 10255-10259.

Kashiwada, Y., Huang, L., Ballas, L. M., Jiang, J. B., Janzen, W. P. \& Lee, K.-H. (1994). J. Med. Chem. 37, 195-200.

Kiupel, B., Niederalt, C., Nieger, M., Grimme, S. \& Vogtle, F. (1998). Angew. Chem. Int. Ed. 37, 3031-3034.

Kochetkov, N. K., Khorlin, A. Y., Chizhov, O. S. \& Sheichenko, V. I. (1962). Bull. Acad. Sci. USSR Div. Chem. Sci. (Engl. Transl.) pp. 797-801.

Kurland, R. J., Rubin, M. B. \& Wise, W. B. (1964). J. Chem. Phys. 40, 2426-2427.

Le Hello, C. (2000). The Alkaloids, Vol. 53, edited by G. A. Cordell, ch. 5. San Diego: Academic Press.

Lee, K.-H. (1999). Med. Res. Rev. 19, 569-596.

Lessinger, L. \& Margulis, T. N. (1978). Acta Cryst. B34, 578584.

Loncar-Tomascovic, L., Sarac-Arneri, R., Hergold-Brundic, A., Nagl, A., Mintas, M. \& Sandström, J. (2000). Helv. Chim. Acta, 83, 479494.

Margulis, T. N. \& Lessinger, L. (1978). Biochem. Biophys. Res. Commun. 83, 472-478.

Mislow, K., Glass, M. A. W., O'Brien, R. E., Rutkin, P., Steinberg, D. H., Weiss, J. \& Djerassi, C. (1962). J. Am. Chem. Soc. 84, 14551478.

Mislow, K., Glass, M. A. W., Hopps, H. B., Simon, E. \& Wahl, G. H. (1964). J. Am. Chem. Soc. 86, 1710-1733.

Miyake, Y., Oyamada, A., Nishibayashi, Y. \& Uemura, S. (2002). Heteroat. Chem. 13, 270-275. 
Mrvoš-Sermek, D., Loncar-Tomaskovic, L., Hergold-Brundic, A., Mintas, M. \& Nagl, A. (1998). Acta Cryst. C54, 877-879.

Nonius BV (1998). COLLECT. Nonius BV, Delft, The Netherlands.

Nyburg, S. C., Prasad, L., Behnam, B. A. \& Hall, D. M. (1988). J. Chem. Soc. Perkin Trans. 2, pp. 617-623.

Otwinowski, Z. \& Minor, W. (1997). Methods in Enzymology, Vol. 276, Macromolecular Crystallography, Part A, edited by C. W.

Cater Jr \& R. M. Sweet, pp. 307-326. New York: Academic Press.

Perrin, D. D., Armarego, W. L. F. \& Perrin, D. R. (1980). Purification of Laboratory Chemicals, 2nd ed. Oxford: Pergamon Press.

Roszak, A. W., Williams, V. E. \& Lemieux, R. P. (1996). Acta Cryst. C52, 3190-3193.

Schmid, R., Cereghetti, M., Heiser, B., Schönholzer, P. \& Hansen, H.-J. (1988). Helv. Chim. Acta, 71, 897-929.
Schneider, M., Linden, A. \& Rippert, A. J. (2000). Acta Cryst. C56, 1004-1006.

Sheldrick, G. M. (1997). SHELXL97 and SHELXS97. University of Göttingen, Germany.

Shi, Q., Chen, K., Brossi, A., Verdier-Pinard, P., Hamel, E., McPhail, A. T. \& Lee, K.-H. (1998). Helv. Chim. Acta, 81, 1023-1037.

Shi, Q., Verdier-Pinard, P., Brossi, A., Hamel, E. \& Lee, K.-H. (1997). Bioorg. Med. Chem. 5, 2277-2282.

Still, W. C., Kahn, M. \& Mitra, A. (1978). J. Org. Chem. 43, 29232925.

Warshawsky, A. M. \& Meyers, A. I. (1990). J. Am. Chem. Soc. 112, 8090-8099.

Widhalm, M., Nettekoven, U. \& Mereiter, K. (1999). Tetrahedron: Asym. 10, 4369-4391.

Wilson, A. J. C. (1976). Acta Cryst. A32, 994-996. 